\title{
Bead Dosing Unit
}

National Cancer Institute

\section{Source}

National Cancer Institute. Bead Dosing Unit. NCI Thesaurus. Code C53495.

A dosing unit equal to the amount of active ing redient(s) contained in a bead. 